\title{
ERRATUM
}

E. Cotter · R.M. O'Riordan · A.A. Myers

\section{A histological study of reproduction in the serpulids Pomatoceros triqueter and Pomatoceros lamarckit (Annelida: Polychaeta)}

Published online: 11 March 2003

(C) Springer-Verlag 2003

\section{Marine Biology DOI 10.1007/s00227-002-0987-2}

Within Discussion, paragraph 1, 'slightly biased to males in $P$. triqueter' should read 'slightly biased to females in P. triqueter'.

Within Discussion, paragraph 9, '(Cotter et al. 2002)' should read '(Cotter et al. 2003)'.

Within References, in Castric-Fey (1983), 'sur les plages expérimentales' should read 'sur les plaques expérimentales'.
Within References, 'Cotter E, O'Riordan RM, Myers AA (2002) Recruitment patterns of serpulids (Annelida: Polychaeta) in Bantry Bay, Ireland. J Mar Biol Assoc UK (in press)' should read 'Cotter E, O'Riordan RM, Myers AA (2003) Recruitment patterns of serpulids (Annelida: Polychaeta) in Bantry Bay, Ireland. J Mar Biol Assoc UK 83:41-48'.

The online version of the original article can be found at http:// dx.doi.org/10.1007/s00227-002-0987-2

E. Cotter $(\bowtie) \cdot$ R.M. O'Riordan · A.A. Myers

Department of Zoology, Ecology, and Plant Science,

National University of Ireland, Cork, Ireland

E-mail: elizabethcotter@vodafone.ie

Fax: + 353-21-4270562

R.M. O'Riordan

Department of Biological Sciences,

National University of Singapore, Singapore 